\title{
Haemoglobin and Red Cell Enzyme Changes in Juvenile Myeloid Leukaemia
}

\author{
D. J. WEATHERALL,* M.D., M.R.c.P. ; J. A. EDWARDS,* M.B., M.R.C.P. ; W. T. A. DONOHOE,* A.I.M.L.T.(S.R.)
}

Brit.med. F., 1968, 1, 679-681

The switchover from foetal to adult haemoglobin synthesis, which is normally complete by the end of the first year of life, is accompanied by marked changes in the red cell enzyme pattern. In particular, the level of carbonic anhydrase, which is very low in cord blood, rapidly increases during the first year of life to become the most abundant of the red cell nonhaemoglobin proteins.

There have been occasional reports of the presence of increased levels of foetal haemoglobin in the red cells of patients with leukaemia (Beaven et al., 1960 ; Shuster et al., 1960 ; Hardisty et al., 1964 ; Weatherall and Walker, 1965). While a slight rise of foetal haemoglobin is not uncommon in a variety of leukaemias, very high levels have been noted only in patients with erythroleukaemia (Beaven et al., 1960) and in children with juvenile myeloid leukaemia (Hardisty et al., 1964). The occurrence of associated changes in red cell enzyme levels has not been noted.

This report describes the changes in haemoglobin and red cell enzyme patterns over a 12 -month period in a child with the clinical features of juvenile myeloid leukaemia and similar studies on 27 children with other types of leukaemia. These studies shed further light on the pathogenesis of juvenile chronic myetoid leukaemia.

\section{Methods and Materials}

Venous blood samples were collected from the child with juvenile myeloid leukaemia at monthly intervals for 12 months. Blood samples were also obtained from children with the types of leukaemia shown in Table I. Haematological studies followed standard techniques. Haemoglobin electrophoresis, visualization of the carbonic anhydrase isozymes by starch-gel electrophoresis, and determination of the total red cell carbonic anhydrase activity were performed by previously reported methods (Weatherall, 1965; Weatherall and McIntyre, 1967). Red cell catalase activity was determined by the method of Hamilton et al. (1961). Titration of the I antigen was carried

TABLE I.-Inoidence of Detectable Foetal Haemoglobin in Childhood Leukaemia

\begin{tabular}{|c|c|c|c|c|}
\hline Type of Leukaemia & & No. Studied & $\begin{array}{c}\text { No. with } \\
\text { Increased } \\
\text { Haemoglobin F F }\end{array}$ & $\underset{F}{\text { Haemoglobin }}$ \\
\hline 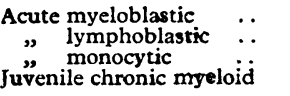 & \begin{tabular}{l|l}
. \\
$\because$ \\
.
\end{tabular} & $\begin{array}{r}3 \\
23 \\
1 \\
1\end{array}$ & $\begin{array}{r}3 \\
15 \\
1 \\
1\end{array}$ & $\begin{array}{l}2-6 \\
1-3 \\
2 \\
65\end{array}$ \\
\hline
\end{tabular}

out with serum from a patient with a high titre of cold agglutinins against cells from at least five adult and cord blood samples as a control for each determination. Blood films were fixed and stained for foetal haemoglobin by the method of Kleihauer et al. (1957). Foetal haemoglobin levels were determined by both alkaline denaturation and chromatographic techniques as previously described (Weatherall, 1965).

\section{Case Report}

A 2-year-old girl first presented to the Maelor General Hospital, N. Wales, in April 1966 with painful blisters on her hands and feet. There had been no previous illnesses and the landmarks of development had been normal. On examination pallor, generalized lymphadenopathy, and hepatosplenomegaly were present. The haematological picture at this time was as follows: haemoglobin $9.6 \mathrm{~g} . / 100$ ml., white cell count $33,000 /$ cu. mm. (P. $43 \%$, L. $22.5 \%$, M. $11.5 \%$, E. $3 \%$, B. $1 \%$, myelocytes $18.5 \%$, blast cells $0.5 \%$ ), platelet count $65,000 /$ cu.mm. The bone marrow at this time was intensely cellular. There was marked proliferation of the white cell precursors at the promyelocytic and myelocytic stages of development, with a slight increase of myeloblasts. The red cell precursors appeared to be scanty but otherwise normal, and very few megakaryocytes were seen. The leucocyte alkaline phosphatase level was low. These findings, together with the changes in haemoglobin constitution described in the next section, led to a diagnosis of juvenile chronic myeloid leukaemia.

After treatment with mercaptopurine, $30 \mathrm{mg}$. daily, there was an increase in well-being associated with a reduction in size of the liver and spleen. The haemoglobin level rose to $12 \mathrm{~g} . / 100 \mathrm{ml}$., the platelet count to $140,000 /$ cu.mm., while the white cell count fell to $6,300 /$ cu.mm. within the next few months. The clinical condition deteriorated six months later with marked splenomegaly, a rising white count, and pronounced thrombocytopenia, the bone marrow picture remaining essentially unchanged. Further treatment with corticosteroids and busulphan (Myleran) produced an improvement in the clinical condition and white cell count, though the thrombocytopenia persisted. Two months later there was further deterioration with marked hepatosplenomegaly and increasing leucocytosis Further treatment with methotrexate, vincristine, and corticosteroids did not improve the clinical picture, and the child died on 6 May 1967.

The haematological findings during the 12 -month period of this child's illness are summarized in Table II. The most striking feature was the persistent thrombocytopenia. The differential white cell count always showed a preponderance of mature polymorphonuclear leucocytes with smaller numbers of myelocytes and scanty

* Nuffield Unit of Medical Genetics, Department of Medicine, University of Liverpool.

TABLE II.-Haematological, Haemoglobin, and Bnzyme Changes During the Course of Patient's Illness

\begin{tabular}{|c|c|c|c|c|c|c|c|c|c|c|c|c|c|c|}
\hline \multirow{3}{*}{ Date } & \multirow{3}{*}{$\begin{array}{c}\text { Haemo- } \\
\text { globin } \\
\text { (g. } 7100 \mathrm{ml} .)\end{array}$} & \multirow{3}{*}{$\begin{array}{l}\text { Platelets } \\
\text { cu. mm }\end{array}$} & \multirow{3}{*}{$\begin{array}{l}\text { W.C.C./ } \\
\text { cu. mm }\end{array}$} & \multirow{2}{*}{\multicolumn{5}{|c|}{ Differential Count (\%) }} & \multirow{3}{*}{$\underset{(\%)}{\text { Hb F }}$} & \multirow{3}{*}{$\underset{(\%)}{\mathrm{Hb}^{2} \mathrm{~A}_{\mathbf{2}}}$} & \multirow{3}{*}{$\begin{array}{c}\text { Carbonic } \\
\text { Anhydrase } \\
\text { (Units/ml. } \\
\text { Packed } \\
\text { Cells) } \\
\end{array}$} & \multicolumn{3}{|c|}{ I Antigen Titres } \\
\hline & & & & & & & & & & & & \multirow{2}{*}{ Patient } & \multicolumn{2}{|c|}{ Control } \\
\hline & & & & $\mathbf{P}$ & L & $\mathbf{M}$ & Myelocytes & Blasts & & & & & Cord & Adult \\
\hline $\begin{array}{c}29 / 4 / 66 \\
28 / 9 / 66 \\
26 / 10 / 66 \\
7 / 11 / 66 \\
19 / 11 / 66 \\
5 / 12 / 66 \\
01 / 167 \\
26 / 1 / 67 \\
8 / 2 / 67 \\
1 / 3 / 67 \\
13 / 3 / 67\end{array}$ & $\begin{array}{c}9.2 \\
11.4 \\
10.8 \\
12.0 \\
11.2 \\
11.9 \\
10.0 \\
9.8 \\
10.0 \\
10.4 \\
10.3\end{array}$ & $\begin{array}{r}80,000 \\
85,000 \\
12,000 \\
20,000 \\
<10,000 \\
<10,000 \\
<10,000 \\
26,000 \\
<10,000 \\
<10,000 \\
<10,000\end{array}$ & $\begin{array}{r}48,000 \\
5,000 \\
33,000 \\
6,000 \\
7,500 \\
9,700 \\
8,000 \\
18,000 \\
12,000 \\
30,700 \\
19,600\end{array}$ & $\begin{array}{l}60 \\
65 \\
82 \\
34 \\
69 \\
60 \\
48 \\
44 \\
62 \\
70 \\
70\end{array}$ & $\begin{array}{r}23 \\
21 \\
4 \\
44 \\
20 \\
25 \\
19 \\
14 \\
12 \\
13 \\
7\end{array}$ & $\begin{array}{r}10 \\
6 \\
12 \\
14 \\
7 \\
14 \\
27 \\
16 \\
16 \\
9 \\
5\end{array}$ & $\begin{array}{l}\frac{4}{1} \\
\frac{1}{7} \\
\frac{1}{17} \\
2 \\
4 \\
6\end{array}$ & $\begin{array}{l}\frac{7}{1} \\
\overline{\overline{1}} \\
\frac{1}{6}\end{array}$ & $\begin{array}{l}20.0 \\
33.3 \\
51.4 \\
53.5 \\
61.7 \\
62.0 \\
55.4 \\
55.8 \\
52.6 \\
60.0 \\
65.5\end{array}$ & $\begin{array}{l}1.6 \\
<0.2 \\
<0.2 \\
<0.2 \\
<0.2 \\
<0.2 \\
<0.2 \\
<0.2 \\
<0.2 \\
<0.2 \\
<0.2\end{array}$ & $\begin{array}{l}\overline{\overline{1}} \\
\overline{160} \\
\overline{920} \\
\overline{900} \\
=\end{array}$ & $\begin{array}{l}256 \\
256 \\
256\end{array}$ & $\begin{array}{l}64 \\
16 \\
16\end{array}$ & $\begin{array}{l}8,192 \\
8,192 \\
8,192 \\
8,192\end{array}$ \\
\hline
\end{tabular}


blast forms. The leucocyte alkaline phosphatase was persistently low and three samples of bone marrow showed an essentially normal karyotype, no Philadelphia chromosome being demonstrated.

\section{Results of Haemoglobin, Enzyme, and Antigenic Studies Haemoglobin Pattern (Table II, Fig 1)}

Blood for haemoglobin electrophoresis was first obtained in April 1966. The haemoglobin pattern on starch-gel electrophoresis (trisborate buffer, $p \mathrm{H}$ 8.8) showed haemoglobins $\mathrm{A}$ and $\mathrm{A}_{2}$ and increased levels of haemoglobin F. Values of $20 \%$ and $1.6 \%$ were obtained for $\mathrm{Hb} F$ and $\mathrm{Hb} \mathrm{A}_{2}$ respectively. The next estimation was performed in September 1966. At this time Hb F comprised 33.3\% of the total haemoglobin while the $\mathrm{Hb} \mathrm{A}_{2}$ level was greatly reduced, being too low for accurate determination (less than $0.5 \%$ ). At this time there was a marked deterioration in the clinical condition, and
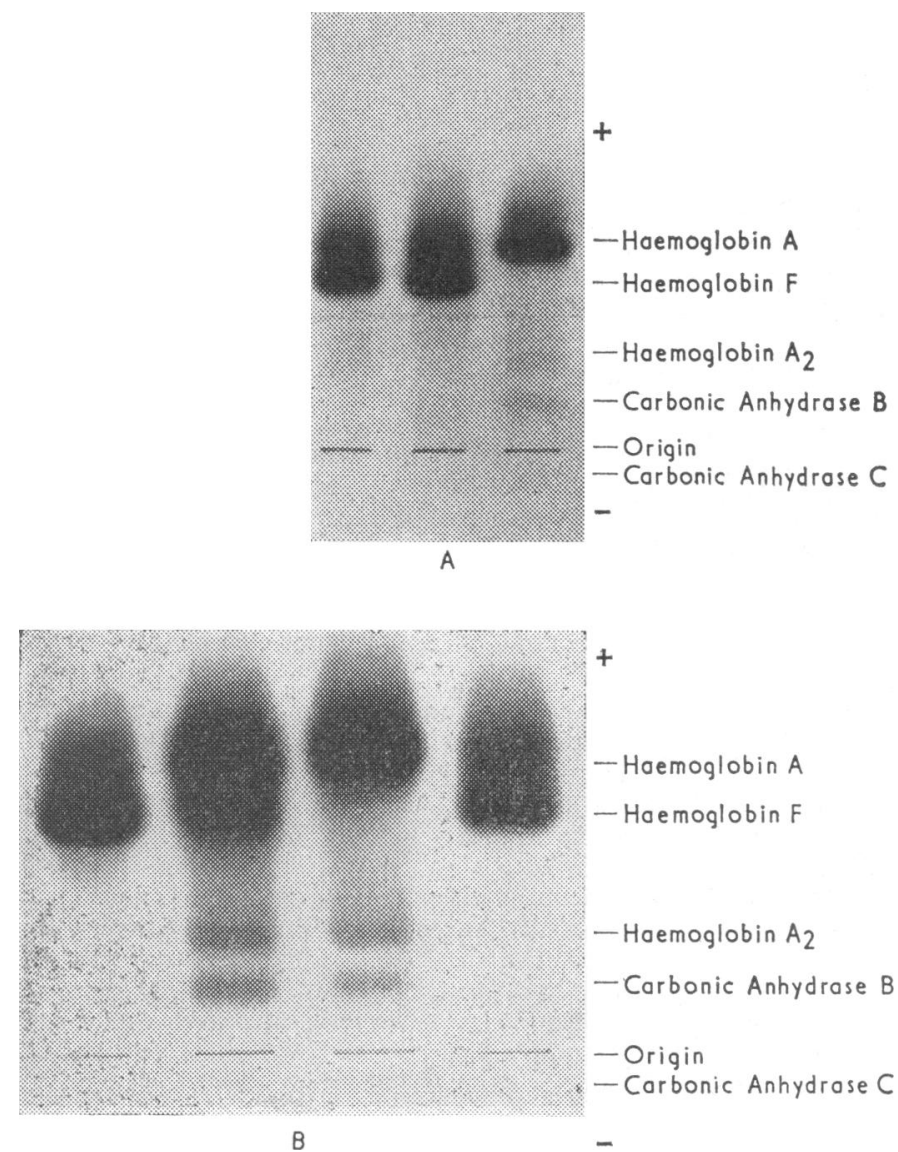
FIG. 1. A, Starch-gel electrophoretic patterns of the following haemo-
lysates (left to right): (1) Patient aged 3 years ; (2) normal umbilical cord ; (3) normal adult (Tris E.D.T.A. borate system, pH 8.8 , amido black (3) normal adult (Tris ). The haemoglobin and non-haem protein components of the patient's cells are identical to those of the cord blood. B, Starch-gel electrophoretic pattern of the following (left to right): (1) normal cord blood ; (2) child of same age as patient, with thalassaemia major and large amount of $\mathrm{Hb} \mathrm{F}$ showing adult $\mathrm{Hb} \mathrm{\textrm {A } _ { 2 }}$ and enzyme pattern; (3) normal adult ; (4) Patient one month before death (gel overloaded to show minor components). Amido black stain. by the second half of October 1966 the $\mathrm{Hb} \mathrm{F}$ level had risen to $51.4 \%$, while only traces of $\mathrm{Hb} \mathrm{A} \mathrm{A}_{2}$ could be detected by starch-gel electrophoresis. The foetal haemoglobin level continued to rise with a transient fall during a partial clinical improvement on restarting mercaptopurine. The final foetal haemoglobin value, before the administration of blood transfusions prevented further estimations, was $65.5 \%$ two months before death. During the last six months of the child's illness only very faint traces of $\mathrm{Hb}_{\mathrm{A}}$ could be demonstrated by starch-gel electrophoresis, the haemoglobin pattern resembling that of a newborn infant (Fig. 1). Electrophoretic studies under a variety of conditions showed no embryonic haemoglobin or other haemoglobin components other than $\mathrm{Hb} \mathbf{A}$ and $\mathrm{F}$, and similar studies combined with column chromatography showed no chemical difference between the $\mathrm{Hb} F$ obtained from the red cells of the patient and that from normal umbilical cord blood.

Staining for $\mathrm{Hb} \mathrm{F}$ by the acid elution technique revealed about $20 \%$ cells showing a foetal pattern in April 1966. The proportion of cells containing foetal haemoglobin continued to rise and few adult "ghost" cells could be identified two months before death (Fig. 2).

\section{Red Cell Enzyme Studies}

Two red cell carbonic anhydrase isozymes, named $B$ and $C$, are readily visible on protein-stained starch-gel electrophoretic patterns of human adult red cell lysates. These bands are absent in normal cord bloods and reach their adult level at about 2 years of age (Weatherall and McIntyre, 1967). In the sample obtained from the patient in May 1966 bands B and C were seen to be slightly reduced but clearly visible. In samples obtained in October 1966 and all subsequent samples, only faint traces of carbonic anhydrase $\mathbf{B}$ and $\mathbf{C}$ could be detected, the pattern resembling that of a normal cord blood sample (Fig. 1). On staining of the gels for carbonic anhydrase activity, with $\beta$-naphthyl acetate as a substrate, no new bands could be seen. Total red cell carbonic anhydrase activity in October 1966 was 1,160 units $/ \mathrm{ml}$. of packed red cells, while the level in February 1967 was 900 units/ml. of packed red cells. Both these values are similar to those found in normal newborn infants.

The red cell esterase pattern after staining gels with $\alpha$ - and $\beta$ naphthyl acetate as substrates was normal, no difference in pattern between adult and cord blood having been noted for these isozymes. The red cell catalase values were not significantly reduced (Kcat 4.48 as compared with Kcat 3.94 for a normal control).

\section{Antigenic Studies}

Results of titrations of the I antigen, which were performed on six occasions, are summarized in Table II. It will be seen that the child's I antigen was appreciably weaker than that of normal adults, though stronger than that of cord blood. There was a tendency for the $I$ antigenicity to fall off during the course of the illness.

\section{Haemoglobin and Enzyme Studies in Other Children with Leukaemia}

Starch-gel electrophoretic studies were performed on one or more occasions on blood samples from 27 children with the types of leukaemia shown in Table I. In addition, fixed blood smears were examined for foetal haemoglobin-containing cells by the method of Kleihauer et al. (1957).
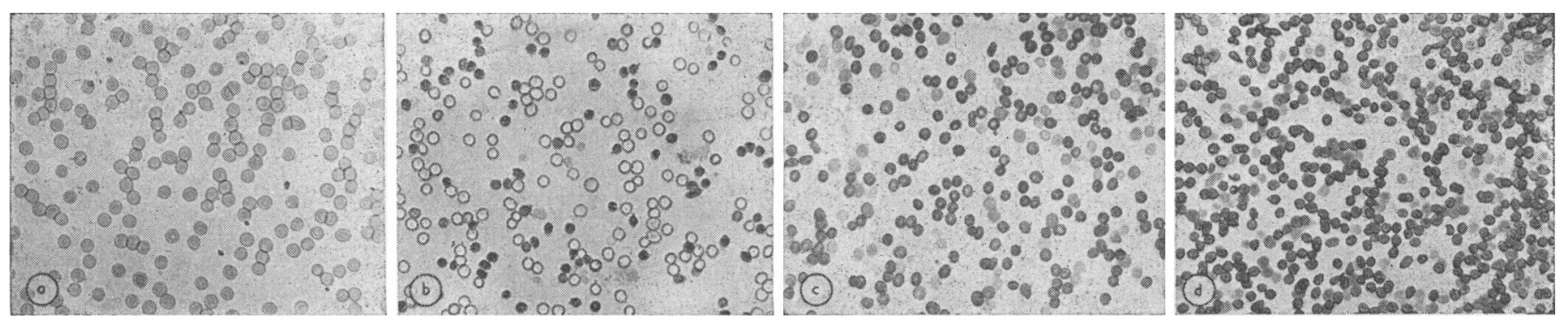

FIg. 2.-Blood films treated by the acid elution technique. (Kleihauer et al., 1957) from the following: (a) Normal adult. (b) Patient during first month of illness. (c) Patient during sixth month of illness. (d) Patient at eleventh month of illness. The foetal haemoglobin-containing cells stain darkly. 
Slight rises of foetal haemoglobin were found in two-thirds of the children with lymphoblastic leukaemia and in all the other forms of acute leukaemia. The carbonic anhydrase isozymes were present in normal amounts in each case, and no abnormal haemoglobin or non-haem components were observed. From use of the slide technique of Kleihauer et al. the foetal haemoglobin appeared to be heterogeneously distributed throughout the red cells. The level of $\mathrm{Hb} \mathrm{F}$ bore no relation to the state of the disease, the number of foetal haemoglobin-containing cells not changing during periods of clinical deterioration.

\section{Discussion}

The clinical and haematological features of juvenile chronic myeloid leukaemia have been recently reviewed (Hardisty et al., 1964). It differs from the adult chronic myeloid leukaemia by a more rapid course, lower total white cell count with a higher proportion of mature polymorphonuclear leucocytes, more pronounced tendency to thrombocytopenia, absence of a Philadelphia chromosome, and high proportion of foetal haemoglobin. The clinical and haematological findings in the case described in the present study are very similar to those described by Hardisty et al. (1964), and are entirely consistent with the diagnosis of juvenile myeloid leukaemia.

Marked rises of foetal haemoglobin levels in children with leukaemia are unusual. The findings in the 26 children with acute leukaemia in this study are similar to those previously described. Thus a slight rise in the $2-5 \%$ range is not uncommon, while higher levels are not usually encountered (Beaven et al., 1960 ; Raper, 1963 ; Weatherall and Walker, 1965). Of the few reported cases of children with leukaemia associated with $\mathrm{Hb} \mathrm{F}$ levels in the 30 to $60 \%$ range, all have shown a clinical picture very similar to that of the child in this study (Shuster et al., 1960 ; Beaven et al., 1960 ; Hardisty et al., 1964). It appears, therefore, that juvenile chronic myeloid leukaemia is the only form of childhood leukaemia in which very high levels of foetal haemoglobin are consistently found. Occasional high values have been noted in adults with erythroleukaemia.

$\mathrm{Hb} \mathrm{A}_{2}$ levels are very low at birth, reaching adult values between 6 and 12 months. In the present case $\mathrm{Hb} \mathrm{A}_{2}$ almost disappeared from the red cells during the course of the illness, coincident with the rise in $\mathrm{Hb} \mathrm{F}$. $\mathrm{Hb} \mathrm{A}_{2}$ levels have not been previously noted in juvenile myeloid leukaemia, though low levels were noted in an adult case of erythroleukaemia (Aksoy and Erdem, 1967). Similarly, carbonic anhydrases B and C are present in very low concentrations at birth, reaching adult levels at 2-3 years (Weatherall and McIntyre, 1967). In this case the level fell during the course of the illness, the electrophoretic pattern of the isozymes and the total red cell activity being identical to those of a newborn infant shortly before the child died. The red cell carbonic anhydrase pattern has been examined both in the 27 children with acute leukaemia in this study and in a previously reported series (Weatherall and McIntyre, 1967) and found to be normal. The level of red cell catalase may be slightly reduced in cord blood samples (Jones and McCance, 1949), but no significant difference in catalase levels between the red cells of the above patient and normal adult controls could be shown.

There has been considerable discrepancy between the published results of I antigen levels in patients with leukaemia. Thus, McGinniss et al. (1964) found I antigenicity to be reduced in 15 out of 40 patients with leukaemia, but this was not confirmed by Feizi and Hardisty (1966). These differences probably reflect the difficulties of titrating this antigen. Iantigen titres in patients with juvenile myeloid leukaemia have not been previously reported. There did appear to have been some reduction of $I$ antigenicity during the course of the patient's illness, though cord blood levels were not reached.

It appears, therefore, that during the 11 months in which this child was observed the haemoglobin and red cell carbonic anhydrase patterns reverted to a foetal form, coincident with a gradual deterioration in the leukaemic picture. This remarkable sequence of events does not occur in other forms of leukaemia and is different from that seen in disorders of development, such as the $D_{1}$ trisomy syndrome, in which the normal switch from foetal to adult haemoglobin and red cell enzyme pattern is delayed (Huehns et al., 1964 ; Lee et al., 1965). Other anaemias which are present from birth, such as the congenital hypoplastic and haemolytic syndromes, are associated with persistent foetal haemoglobin synthesis, but the red cell enzymes and minor adult haemoglobin components develop normally. It is doubtful if the findings in this case are in any way connected with the early age of onset of the leukaemia, since the rate of decline of foetal haemoglobin was normal in a recently described case of an 8-month-old child with the adult type of chronic myeloid leukaemia (Bloom et al., 1966).

The findings in this child are in agreement with the suggestion that juvenile myeloid leukaemia is a congenital disorder (Hardisty et al., 1964). Thus it is possible that the disease follows the abnormal proliferation of a "rest" of stem cells in which the normal processes of differentiation have not occurred. Such a situation would result, as the disease progresses, in the gradual disappearance of the adult major and minor haemoglobins and of the enzymes which appear during the first few months of life. An alternative explanation would be that of a somatic mutation in the abnormal cell line, but since there is evidence that the haemoglobin genes and those controlling the carbonic anhydrase isozymes are not contained within the same operon (Weatherall, 1965), such a mechanism seems less likely.

Clearly, further work along these lines is required to define the disorder of "juvenile chronic myeloid leukaemia." A recent report of red cell enzyme and haemoglobin changes similar to those found in the present study, in a 47-year-old man with features suggestive of leukaemia (Lie-Injo and Tarail, 1966), suggests that this type of syndrome may not be unique to childhood. Further studies of these syndromes may throw valuable light on the nature of leukaemic reactions in general.

\section{Summary}

The haemoglobin and red cell enzyme pattern reverted to the foetal form in a young girl with juvenile chronic myeloid leukaemia. These changes have not been found in other forms of childhood leukaemia and provide evidence of the nature of juvenile myeloid leukaemia.

These studies were made possible through the kind co-operation of the paediatricians and pathologists at Alder Hey and Maelor General Hospitals, in particular the late Dr. S. E. Keidan, Dr. D.
Mainwaring, Dr. E. G. Hall, Dr. M. J. Bouton, Dr. E. G. G. Roberts, and Dr. L. N. Wise. We would also like to thank Dr. S. Walker for the chromosomal analysis.

\section{REFERENCES}

Aksoy, M., and Erdem, S. (1967). Nature (Lond.), 213, 522. Beaven, G. H., Ellis, M. J., and White, J. C. (1960). Brit. F. Haemat., 6,

Bloom, G. E., Gerald, P. S., and Diamond, L. K. (1966). Pediatrics, 38, 295 .

Feizi, T., and Hardisty, R. M. (1966). Nature (Lond.), 210, 1066.

Feizi, T., and Hardisty, R. M. (1966). Nature (Lond.), 210, 1066. clin. Invest., 40, 2199.

Hardisty, R. M., Speed, D. E., and Till, M. (1964). Brit. F. Haemat., 10, 551.

Huehns, E. R., Hecht, F., Keil, J. V., and Motulsky, A. G. (1964). Proc. nat. Acad. Sci. (W ash.), 51, 89.

Jones, P. E. H., and McCance, R. A. (1949). Biochem. F., 45, 464.

Kleihauer, E., Braun, H., and Betke, K. (1957). Klin. Wschr., 35, 637.

Lee, C. S N., et al. (1966). Bull. Fohns Hopk. Hosp., 118, 374.

Lie-Injo Luan Eng and Tarail, R. (1966). Nature (Lond.), 211, 47.
McGinniss, M. H., Schmidt, P. J., and Carbone, P. P. (1964). Natur McGinniss, M. H., Schmidi, P. J., and Carbone, P. P. (1964). Nature (Lond.), 202, 606.

Raper, A. B. (1963). Arch. Dis. Childh., 38, 553.

Shuster, S., Jones, J. H., and Kilpatrick, G. S. (1960). Brit. med. F., 2, 1556.

Weatherall, D. J. (1965). The Thalassaemia Syndromes. Oxford.

Weatherall, D. J., and McIntyre, P. A. (1967). Brit. F. Haemat., 13, 106.

Weatherall, D. J., and Walker, S. (1965). f. med. Genet., 2, 212. 